\title{
RAPID
}

PUBLICATION

\section{Cytochemical Localization of}

\section{$\mathrm{Na}^{+}, \mathrm{K}^{+}$-ATPase in the Rat Hepatocyte}

\author{
Bennett L. Blitzer and JAmes L. Boyer, Liver Study Unit, Department of Medicine, \\ University of Chicago, Chicago, Illinois 60637
}

\begin{abstract}
A B S T R A C T The enzyme $\mathrm{Na}^{+}, \mathrm{K}^{+}$-ATPase was cytochemically localized in the rat hepatocyte by a modification of the Ernst potassium-dependent nitrophenyl phosphatase technique. Measurement of nitrophenol release from $50-\mu \mathrm{m}$ liver slices confirmed the presence of ouabain-inhibitable nitrophenyl phosphatase activity that increased over the 30 -min incubation period. Electron micrographs demonstrated that sinusoidal and lateral membrane reaction product deposition was $\mathrm{K}^{+}$-dependent, $\mathrm{Mg}^{++}$-dependent, inhibited by ouabain but not by alkaline phosphatase inhibitors, and was localized to the cytoplasmic side of the membrane. In contrast, canalicular reaction product was $\mathrm{K}^{+}$-independent, $\mathrm{Mg}^{++}$-dependent, inhibited by alkaline phosphatase inhibitors but not by ouabain, and was localized to the luminal side of the membrane. These findings indicate that $\mathrm{Na}^{+}, \mathrm{K}^{+}$-ATPase is localized to the sinusoidal and lateral portions of the rat hepatocyte plasma membrane and is not detectable on the bile canaliculus where alkaline phosphatase is confined. This basolateral localization of $\mathrm{Na}^{+}, \mathrm{K}^{+}$-ATPase is similar to that found in epithelia where secretion is also directed across the apical membrane.
\end{abstract}

Portions of this work were presented at the Annual Meeting of the American Gastroenterological Association, 22 May 1978. Gastroenterology. 74: 1169.

Dr. Blitzer is a recipient of a U.S. Public Health Service fellowship 1-F32-AMO5838-01 and Dr. Boyer is a recipient of an Academic Career Development Award from the National Institute of Arthritis, Metabolism, and Digestive Diseases (AM 70218).

The present address of Doctors Blitzer and Boyer is Liver Study Unit, Department of Medicine, Yale University School of Medicine, New Haven, Conn. 06510.

Received for publication 24 July 1978 and in revised form 14 August 1978.

\section{INTRODUCTION}

The activity of the enzyme sodium-potassium-activated adenosine triphosphatase $\left(\mathrm{Na}^{+}, \mathrm{K}^{+}\right.$-ATPase) in hepatocyte surface membrane fractions has been correlated with changes in bile acid-independent bile flow under a variety of experimental conditions (1-4). This relationship has led, in turn, to the hypothesis that sodium transport is a major determinant of canalicular bile secretion. However, the precise role of this enzyme in bile formation has not been established and this is, in part, because of uncertainty as to whether $\mathrm{Na}^{+}, \mathrm{K}^{+}$ ATPase is localized apically, on the canalicular membrane, or basolaterally, on the sinusoidal and lateral membranes.

In the present study, we have localized $\mathrm{Na}^{+}, \mathrm{K}^{+}$ATPase in the rat hepatocyte by a modification of the Ernst cytochemical technique (5-7) which exploits the well-described potassium-dependent nitrophenyl phosphatase activity of $\mathrm{Na}^{+}, \mathrm{K}^{+}$-ATPase (5).

\section{METHODS}

\section{Animals}

Male Sprague-Dawley rats (Charles River Breeding Laboratories, Wilmington, Mass.) were maintained in a constant temperature environment $\left(22^{\circ} \mathrm{C}\right)$ with alternate 12 -h light and dark cycles and fed Purina lab chow (Ralston Purina Co., St. Louis, Mo.) ad libitum. Before an experiment, rats were fasted overnight but allowed free access to water. Body weights were between 200 and $290 \mathrm{~g}$.

\section{Perfusion fixation and preparation of sections}

On the morning of the study, after the rats were anesthetized with pentobarbital ( $5 \mathrm{mg} / 100 \mathrm{~g}$ body wt i.p.) and 
heparinized (500 IU/100 g body wt i.v.), iced normal saline was infused at $15 \mathrm{~cm}$ pressure via the portal vein until the liver had blanched. Then, 3\% paraformaldehyde- $0.25 \%$ glutaraldehyde in $0.1 \mathrm{M}$ cacodylate buffer ( $\mathrm{pH} 7.5)$ chilled to $4^{\circ} \mathrm{C}$ was infused for $4 \mathrm{~min}$ at $15 \mathrm{~cm}$ pressure. Liver tissue blocks $(3 \times 10 \mathrm{~mm})$ were cut from the center of a hepatic lobe, rinsed once in $0.1 \mathrm{M}$ cacodylate buffer $(\mathrm{pH} 7.5)$ and twice in $0.1 \mathrm{M}$ Tris- $\mathrm{HCl}$ buffer ( $\mathrm{pH} 7.5$ ), mounted in Styrofoam (Dow Chemical Co., Midland, Mich.), and 50- $\mu \mathrm{m}$ sections were cut on an Oxford Vibratome (Oxford Laboratories Inc., Foster City, Calif.), with a time elapse of approximately 45 min before incubation.

\section{Cytochemical conditions}

Standard medium. Sections were incubated in a phosphatase medium similar to that employed by Ernst (7) and that contained: $20 \mathrm{mM}$ disodium $p$-nitrophenyl phosphate, $20 \mathrm{mM} \mathrm{MgCl}_{2}, 30 \mathrm{mM} \mathrm{KCl}, 20 \mathrm{mM} \mathrm{SrCl}_{2}$, and $250 \mathrm{mM}$ Tris$\mathrm{HCl}$ buffer $\mathrm{pH}$ 9.0. The reaction was initiated by the addition of two to three tissue sections to $7 \mathrm{ml}$ of medium, which was then incubated at $37^{\circ} \mathrm{C}$ for $30 \mathrm{~min}$ in a shaking water bath. Sections were then rinsed three times with $0.1 \mathrm{M}$ Tris- $\mathrm{HCl}$ buffer ( $\mathrm{pH} \mathrm{9.0)}$ at room temperature. To convert precipitated strontium phosphate to the more electron-dense lead phosphate, sections were treated with two 5-min exchanges of $2 \%$ lead nitrate. Sections were then washed twice with $0.1 \mathrm{M}$ cacodylate buffer ( $\mathrm{pH} 7.5$ ), postfixed with $1 \%$ osmium tetroxide, rinsed in tap water, dehydrated in ethanol, and embedded in Epon (Shell Chemical Co., Houston, Tex.) resin. Thin sections for transmission electron microscopy were cut on a Porter-Blum microtome (Dupont Instruments, Sorvall Operations, Newtown, Conn.), stained with uranyl acetate and lead citrate, and examined on a Siemens Elmiskop 1A electron microscope (Siemens Corp., Medical/Industrial Groups, Iselin, N. J.).

Control media. To distinguish reaction product caused by $\mathrm{Na}^{+}, \mathrm{K}^{+}$-ATPase from that caused by nonspecific alkaline phosphatase, sections were also incubated in media which either contained enzyme inhibitors or omitted essential cations as follows: ( $a$ ) alkaline phosphatase inhibitors ( $10 \mathrm{mM}$ L-cysteine or $1 \mathrm{mM}$ L-tetramisole), ${ }^{1}(b) \mathrm{Na}^{+}, \mathrm{K}^{+}$-ATPase inhibitor $(2.5 \mathrm{mM}$ ouabain), (c) cation dependence: $\left(\mathrm{K}^{+}\right.$or $\mathrm{Mg}^{++}$omission). In addition, alkaline phosphatase activity was specifically localized with $20 \mathrm{mM}$ disodium $\beta$-glycerophosphate as substrate. As a final control, a substrate-deficient medium was also used. At least four to five separate experiments were performed with each medium.

\section{Ouabain-inhibitable nitrophenol release}

To validate the specificity of the reaction in rat liver tissue slices, the release of nitrophenol was measured spectrophotometrically at $420 \mathrm{~nm}$ in complete media and in media that contained ouabain without $\mathrm{K}^{+}$as previously described $(5,8,9)$. Cysteine $(10 \mathrm{mM})$ was added to both media to reduce background alkaline phosphatase activity.

All chemicals were reagent grade. All buffers and lead nitrate were supplemented with sucrose to an osmolality of $\cong 310$ mosmol (except for fixative and incubation buffers).

\section{RESULTS}

Total nitrophenol release from liver slices incubated in complete medium increased linearly over $30 \mathrm{~min}$ when measured spectrophotometrically. Ouabain-inhibitable activity also increased (averaging $0.25 \mathrm{nmol}$ of nitrophenol released/mg per min) but represented only $\cong 10 \%$ of total activity.

Electron micrographs of sections incubated in the standard medium showed reaction product on the sinusoidal microvilli, lateral cell membranes, and canalicular microvilli. At high power, sinusoidal and lateral reaction product was always localized to the cytoplasmic side of the membrane (Fig. 1) whereas canalicular reaction product was localized to the luminal side of the membrane (Fig. 2).

Inhibitors of alkaline phosphatase $(10 \mathrm{mM}$ cysteine or $1 \mathrm{mM}$ tetramisole) markedly reduced canalicular reaction product deposition (Fig. 3). Residual canalicular reaction product was confined exclusively to the luminal surfaces of the membrane. In contrast, sinusoidal and lateral reaction product deposition was not diminished and even appeared to increase with cysteine and was always localized to the cytoplasmic side of the membrane (Fig. 3).

Ouabain, a specific inhibitor of $\mathrm{Na}^{+}, \mathrm{K}^{+}$-ATPase, virtually abolished sinusoidal and lateral reaction product deposition even in the presence of cysteine (Fig. 4) but did not affect canalicular reaction product. Similar results were obtained when potassium was omitted from the medium (Fig. 5). Furthermore, $\mathrm{K}^{+}$ omission did not affect residual canalicular product in the presence of cysteine.

When $\beta$-glycerophosphate, a substrate for alkaline phosphatase but not for $\mathrm{Na}^{+}, \mathrm{K}^{+}$-ATPase, was substituted for nitrophenyl phosphate, no reaction product was found on the sinusoidal or lateral membranes but was heavy on the luminal side of the canalicular membrane. Omission of magnesium from the medium markedly diminished both sinusoidal and lateral and canalicular reaction product deposition.

In a substrate-free medium, no reaction product deposition was seen. However, in media that contained nitrophenyl phosphate, fine grains of reaction product were occasionally observed along the nuclear envelope and rarely in association with mitochondria and endoplasmic reticula. Ernst found similar variable reaction product deposition in these subcellular organelles and has demonstrated that this represents artifactual nonenzymatic binding of lead precipitates $(6,7)$.

\section{DISCUSSION}

The Ernst nitrophenyl phosphatase technique has been used to localize $\mathrm{Na}^{+}, \mathrm{K}^{+}$-ATPase in a large number of

\footnotetext{
${ }^{1}>95 \%$ Purity kindly provided by Dr. J. Piotrowski, American Cyanamid Co., Princeton, N. J.
} 

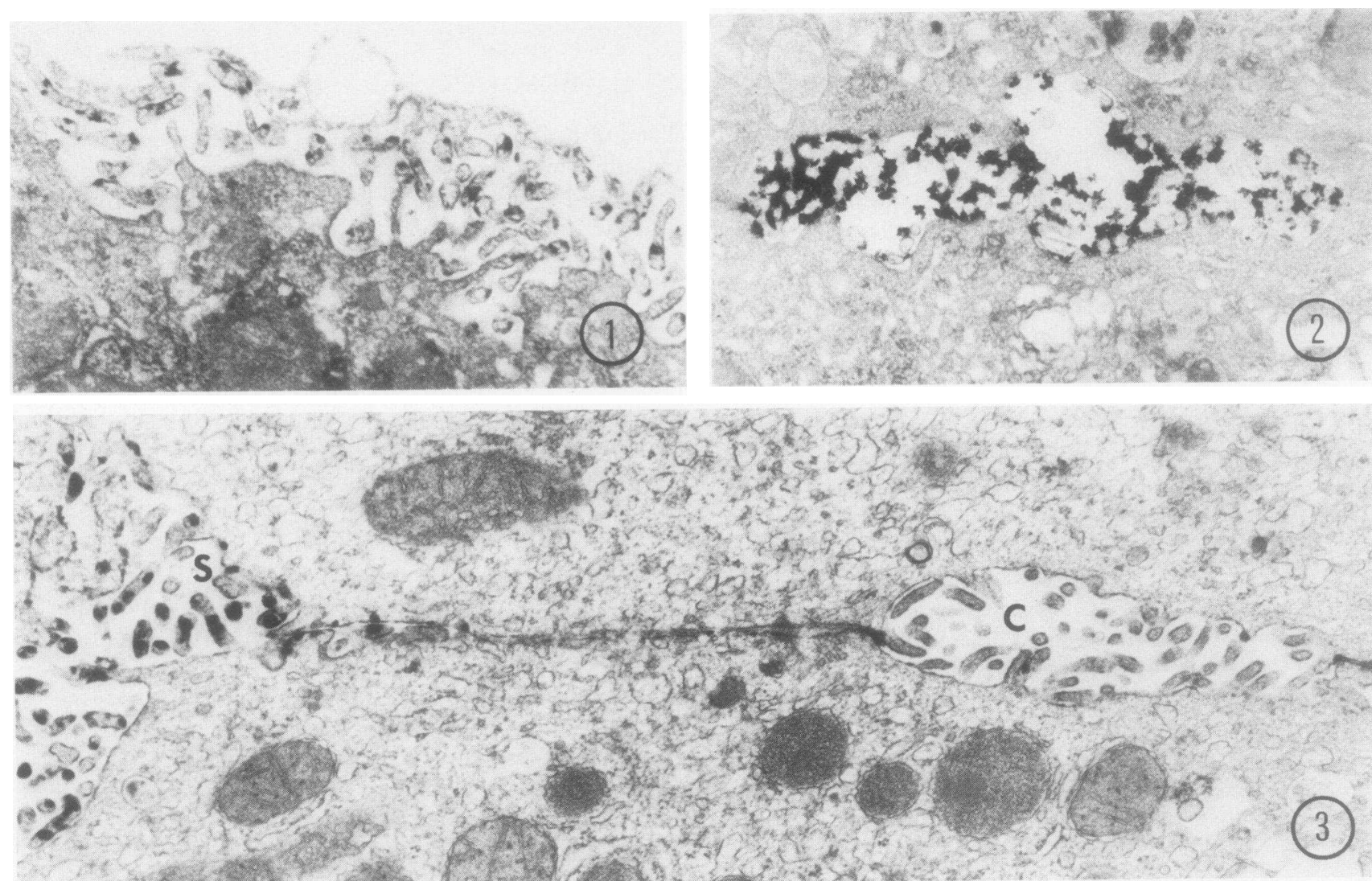

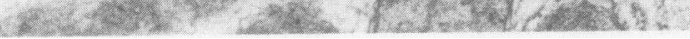

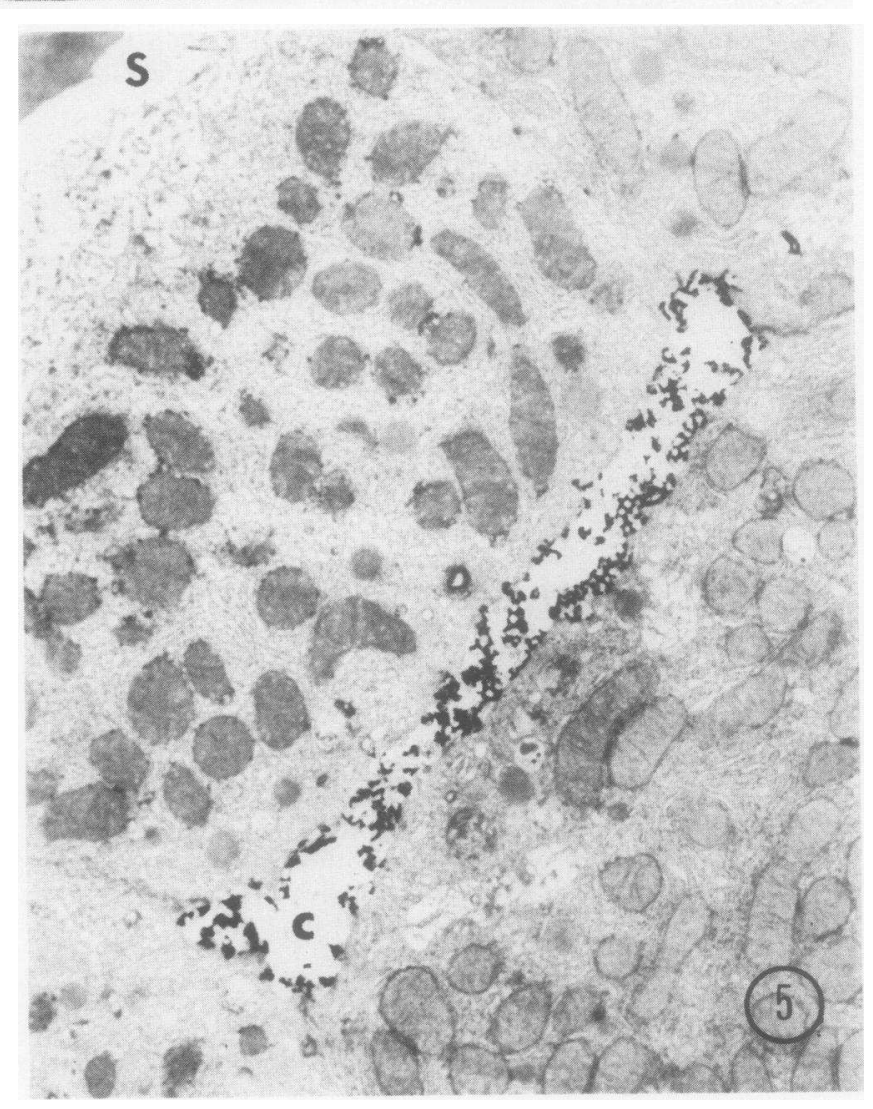


epithelia from a variety of species. ${ }^{2}$ The underlying assumption of this method is that $\mathrm{K}^{+}$-dependent nitrophenyl phosphatase activity represents the terminal phosphatase step of $\mathrm{Na}^{+}, \mathrm{K}^{+}$-ATPase. Biochemical evidence to support this view has been reviewed in detail by Emst (5) and there has been an excellent correlation with independent methods for the localization of $\mathrm{Na}^{+}, \mathrm{K}^{+}$-ATPase such as $\left[{ }^{3} \mathrm{H}\right]$ ouabain autoradiography $(12)$ and immunocytochemical techniques $(13,14)$. Our findings in the rat hepatocyte indicate that $\mathrm{Na}^{+}, \mathrm{K}^{+}$-ATPase is localized to the sinusoidal and lateral portions of the rat hepatocyte surface membrane and is not detectable on the bile canalicular membrane where nonspecific alkaline phosphatase activity is confined. Although we can not absolutely exclude the possibility that small amounts of canalicular $\mathrm{Na}^{+}, \mathrm{K}^{+}$-ATPase activity were obscured by the larger amount of alkaline phosphatase activity, several other observations make this highly unlikely. First, as shown in other epithelia (6-9), $\mathrm{K}^{+}$-dependent, ouabain-inhibitable reaction product deposition is clearly localized to the cytoplasmic side of the membrane. This is consistent with internal phosphate release as predicted from the known membrane asymmetry of $\mathrm{Na}^{+}, \mathrm{K}^{+}$-ATPase for its substrates (15). In contrast, canalicular reaction product was always on the luminal side of the membrane. Repeated examination of high power electron micrographs failed to reveal any reaction product on the cytoplasmic side of the canalicular membrane in any of our studies. Additionally, when residual canalicular reaction product deposition in the presence of cysteine was examined, it was always luminal and was not further reduced by ouabain or potassium omission unlike the sinusoidal deposits. Furthermore, addition of cys-

\footnotetext{
${ }^{2}$ Including: avian salt gland (6), rat cornea (10), iguana nasal gland (11), rat renal cortex (7), dogfish rectal gland (8), and turtle lacrimal gland (9).
}

teine actually resulted in an increase in basolateral reaction product. This is consistent with the finding that cysteine enhances $\mathrm{Na}^{+}, \mathrm{K}^{+}$-ATPase activity in partially purified preparations (16).

Our finding that $\mathrm{Na}^{+}, \mathrm{K}^{+}$-ATPase is localized to the sinusoidal and lateral cell membranes would at first appear to be discordant with data from studies of partially purified hepatocyte surface membrane fractions. These investigations have demonstrated significant $\mathrm{Na}^{+}, \mathrm{K}^{+}$-ATPase activity in canalicular-enriched membrane fractions and correlated changes in the specific activity of this membrane enzyme with alterations in bile acid-independent bile flow (1-4). However, these fractions, which are prepared by discontinuous sucrose gradient sedimentation methods, are merely enriched in canaliculi and contain a variety of elements derived from both the surface membrane and from subcellular organelles as evidenced by transmission electron microscopy and measurement of enzyme markers (1-4). Hence $\mathrm{Na}^{+}, \mathrm{K}^{+}$-ATPase might be localized to membrane fragments from sinusoidal and lateral cell surfaces contaminating canalicular-enriched plasma membrane preparations. Data from Evans (17) and colleagues would support this hypothesis because they found $\mathrm{Mg}^{++}$-ATPase activity but no $\mathrm{Na}^{+}, \mathrm{K}^{+}$-ATPase in a light subfraction of mouse liver prepared by zonal centrifugation which appeared to be canalicular-derived. In contrast, a heavy subfraction which appeared to contain sinusoidal and lateral membranes showed significant $\mathrm{Na}^{+}, \mathrm{K}^{+}$-ATPase activity but no $\mathrm{Mg}^{++}$-ATPase activity.

The basolateral localization of $\mathrm{Na}^{+}, \mathrm{K}^{+}$-ATPase in the present study is similar to that found in a large number of secretory epithelia with the sole exception of the choroid plexus where the enzyme was localized apically (18). Theories of hepatocyte bile formation must take into account this basolateral localization of $\mathrm{Na}^{+}, \mathrm{K}^{+}$-ATPase, because our findings if confirmed, are

Figures 1-5 Electron micrographs of $50-\mu \mathrm{m}$ liver slices incubated at $37^{\circ} \mathrm{C}$ for $30 \mathrm{~min}$ in media that contained: $20 \mathrm{mM}$ disodium $p$-nitrophenyl phosphate, $20 \mathrm{mM} \mathrm{MgCl}, 30 \mathrm{mM} \mathrm{KCl}$ (except Fig. 5), $20 \mathrm{mM} \mathrm{SrCl}$, and $250 \mathrm{mM}$ Tris-HCl buffer pH 9.0. Inhibitors were added as indicated.

FIgURE 1 Sinusoidal reaction product is localized to the cytoplasmic side of the microvilli (standard medium). $\times 35,000$.

FIGURE 2 Reaction product is heavily deposited along the luminal side of the canalicular microvilli (standard medium). $\times 17,000$.

FIGURE 3 In a medium that contained $10 \mathrm{mM}$ L-cysteine, sinusoidal (S), and lateral membrane reaction product deposition is increased and localized to the cytoplasmic side of the membrane while canalicular $(C)$ reaction product is markedly reduced and localized to the luminal side of the membrane. $\times 27,200$.

FIGURE 4 In a medium that contained $2.5 \mathrm{mM}$ ouabain and $10 \mathrm{mM}$ L-cysteine, sinusoidal (S) microvillar reaction product deposition is virtually abolished. $\times 30,000$.

FIgURE 5 Potassium omission. Sinusoidal (S) reaction product is markedly reduced and canalicular $(\mathrm{C})$ reaction product is unaltered. $\times 9,600$. 
obviously inconsistent with a simple enzyme-mediated sodium-potassium exchange across the canalicular membrane.

\section{ACKNOIVLEDG.MENTS}

The authors are indebted to Dr. Zdenek Hruban for his generous advice, to Mrs. S. F. Chou for technical assistance, and to Ms. Kathy Linneman for expert secretarial assistance.

This work was supported by U. S. Public Health Service Research grant A.M 17153 and U. S. Public Health Service Training grant 1T32-AM07074.

\section{REFERENCES}

1. Layden, T. J., and J. L. Boyer. 1976. The effect of thyroid hormone on bile salt-independent bile flow and $\mathrm{Na}^{+}, \mathrm{K}^{+}$-ATPase activity in liver plasma membranes enriched in bile canaliculi. J. Clin. Invest. 57: 1009-1018.

2. Simon, F. R., E. Sutherland, and L. Accatino. 1977. Simulation of hepatic sodium and potassium-activated adenosine triphosphatase activity by phenobarbital. J. Clin. Invest. 59: 849-861.

3. Reichen, J., and G. Paumgartner. 1977. Relationship between bile flow and $\mathrm{Na}^{+}, \mathrm{K}^{+}$-adenosinetriphosphatase in liver plasma membranes enriched in bile canaliculi. $J$. Clin. Invest. 60: 429-434.

4. Wannagat, F-J., R. D. Adler, and R. K. Ockner. 1978. Bile acid-induced increase in bile acid-independent flow and plasma membrane NaK-ATPase activity in rat liver. $J$. Clin. Invest. 61: 297-307.

5. Ernst, S. A. 1972. Transport adenosine triphosphatase cytochemistry. I. Biochemical characterization of a cytochemical medium for the ultrastructural localization of ouabain-sensitive, potassium-dependent phosphatase activity in the avian salt gland. J. Histochem. Cytochem. 20: $13-22$.

6. Ernst, S. A. 1972. Transport adenosine triphosphatase cytochemistry. II. Cytochemical localization of ouabainsensitive, potassium-dependent phosphatase activity in the secretory epithelium of the avian salt gland. $J$. Histochem. Cytochem. 20: 23-38.

7. Ernst, S. A. 1975. Transport ATPase cytochemistry: Ultrastructural localization of potassium-dependent and potassium-independent phosphatase activities in rat kidney cortex. J. Cell Biol. 66: 586-608.

8. Goertemiller, C. C., Jr., and R. A. Ellis. 1976. Localization of ouabain-sensitive, potassium-dependent nitrophenyl phosphatase in the rectal gland of the spiny dogfish, Squalus acanthias. Cell Tissue Res. 175: 101-112.

9. Ellis, R. A., and C. C. Goertemiller, Jr. 1976. Scanning electron microscopy of intercellular channels and the localization of ouabain sensitive p-nitrophenyl phosphatase activity in the salt secreting lacrimal glands of the marine turtle Chelonia mydas. Cytobiologie. 13: 1-12.

10. Leuenberger, P. M., and A. B. Novikoff. 1974. Localization of transport adenosine triphosphatase in rat cornea. J. Cell Biol. 60: 721-731.

11. Ellis, R. A., and C. C. Goertemiller, Jr. 1974. Cytological effects of salt-stress and localization of transport adenosine triphosphatase in the lateral nasal glands of the desert iguana. Dipsosarus dorsalis. Anat. Rec. 180: 285298.

12. Ernst, S. A., and J. W. Mills. 1977. Basolateral plasma membrane localization of ouabain-sensitive sodium transport sites in the secretory epithelium of the avian salt gland. J. Cell Biol. 75: 74-94.

13. Kyte, J. 1976. Immunoferritin determination of the distribution of $\left(\mathrm{Na}^{+}+\mathrm{K}^{+}\right)$ATPase over the plasma membranes of renal convoluted tubules. I. Distal segment. J. Cell Biol. 68: 287-303.

14. Kyte, J. 1976. Immunoferritin determination of the distribution of $\left(\mathrm{Na}^{+}+\mathrm{K}^{+}\right)$ATPase over the plasma membranes of renal convoluted tubules. II. Proximal segment. J. Cell Biol. 68: 304-318.

15. Whittam, R. 1962. The asymmetrical stimulation of a membrane adenosine triphosphatase in relation to active cation transport. Biochem. J. 84: 110-118.

16. Specht, S. C., and J. D. Robinson. 1973. Stimulation of the $\left(\mathrm{Na}^{+}+\mathrm{K}^{+}\right)$-dependent adenosine triphosphatase by amino acids and phosphatidylserine: Chelation of trace metal inhibitors. Arch. Biochem. Biophys. 154: 314-323.

17. Evans, W. H. 1970. Fractionation of liver plasma membranes prepared by zonal centrifugation. Biochem J. 166: 833-842.

18. Quinton, P. M., E. M. Wright, and J. M. Tormey. 1973. Localization of sodium pumps in the choroid plexus epithelium. J. Cell Biol. 58: 724-730. 